\title{
Correction to: Effects of enzymatically modified isoquercitrin in supplementary protein powder on athlete body composition: a randomized, placebo- controlled, doubleblind trial
}

Naomi Omi ${ }^{1,2^{*}}$, Hideki Shiba ${ }^{2}$, Eisaku Nishimura ${ }^{3}$, Sakuka Tsukamoto ${ }^{3}$, Hiroko Maruki-Uchida ${ }^{3}$, Masaya Oda ${ }^{2}$ and Minoru Morita ${ }^{3}$

\section{Correction to: J Int Soc Sports Nutr https://doi.org/10.1186/s12970-019-0303-x}

The original article [1] contained a typesetting error in Table 3 which was mistakenly introduced by the production team handling this article; this error has now been corrected.

\section{Author details}

${ }^{1}$ Faculty of Health and Sport Sciences, University of Tsukuba, Tsukuba, Japan. ${ }^{2}$ Physical Education Graduate School, University of Tsukuba, Tsukuba, Japan.

${ }^{3}$ Health Science Research Center, Morinaga \& Co., Ltd, Tokyo, Japan.

Published online: 21 October 2019

\section{Reference}

1. Omi N, Shiba H, Nishimura E, Tsukamoto S, Maruki-Uchida H, Oda M, Morita M. Effects of enzymatically modified isoquercitrin in supplementary protein powder on athlete body composition: a randomized, placebo-controlled, doubleblind trial. J Int Society Sports Nutr. 2019;16:39 https://doi.org/10. 1186/s12970-019-0303-x.

\footnotetext{
* Correspondence: ominaomi@taiiku.tsukuba.ac.jp

${ }^{1}$ Faculty of Health and Sport Sciences, University of Tsukuba, Tsukuba, Japan

${ }^{2}$ Physical Education Graduate School, University of Tsukuba, Tsukuba, Japan

Full list of author information is available at the end of the article
}

(c) The Author(s). 2019 Open Access This article is distributed under the terms of the Creative Commons Attribution 4.0 International License (http://creativecommons.org/licenses/by/4.0/), which permits unrestricted use, distribution, and reproduction in any medium, provided you give appropriate credit to the original author(s) and the source, provide a link to the Creative Commons license, and indicate if changes were made. The Creative Commons Public Domain Dedication waiver (http://creativecommons.org/publicdomain/zero/1.0/) applies to the data made available in this article, unless otherwise stated. 